\title{
Plant Hardiness Zone Map in Korea and an Analysis of the Distribution of Evergreen Trees in Zone 7b
}

\author{
Jung Nam Suh ${ }^{1}$, Yun-Im Kang ${ }^{1}$, Youn Jung Choi ${ }^{1}$, Kyung Hye Seo ${ }^{1}$, and Yong Hyun Kim ${ }^{2 *}$ \\ ${ }^{1}$ Researcher, National Institute of Horticultural and Herbal Science, Rural Development Administration, Wanju-gun, Jeollabuk-do 55365, \\ Korea \\ ${ }^{2}$ Postdoctoral researcher, National Institute of Horticultural and Herbal Science, Rural Development Administration, Wanju-gun, Jeollabuk-do \\ 55365, Korea
}

\section{ABSTRACT}

Background and objective: This study was conducted to establish a Plant Hardiness Zone (PHZ) map, investigate the effect of global warming on changes in $\mathrm{PHZ}$, and elucidate the difference in the distribution of evergreen trees between the central and southern region within hardiness Zone $7 \mathrm{~b}$ in Korea.

Methods: Mean annual extreme minimum temperature (EMT) and related temperature fluctuation data for 40 years (1981 to 2020) in each of the meteorological observation points were extracted from the Open MET Data Portal of the Korea Meteorological Administration. Using EMT data from 60 meteorological observation points, PHZs were classified according to temperature range in the USDA Plant Hardiness Zone Map. Changes in PHZs for each decade related to the effects of global warming were analyzed. Temperature fluctuation before and after the day of EMT were analyzed for 4 areas of Seoul, Suwon, Suncheon, and Jinju falling under Zone 7b. For statistical analysis, descriptive statistics and ANOVA were performed using the IBM SPSS 22 Statistics software package.

Results: Plant hardiness zones in Korea ranged from 6a to 9b. Over four decades, changes to warmer PHZ occurred in 10 areas, especially in colder ones. Based on the analysis of daily temperature fluctuation, the duration of sub-zero temperatures was at least 2 days in Seoul and Suwon, while daily maximum temperatures were above zero in Suncheon and Jinju before and after EMT day.

Conclusion: It was found that the duration of sub-zero temperatures in a given area is an important factor affecting the distribution of evergreen trees in PHZ 7b.

Keywords: extreme minimum temperature (EMT), global warming, meteorological data, temperature fluctuation

\section{Introduction}

There are several factors essential for the survival of plants, such as light, temperature, and moisture, which act in a complex manner. Of these, as an environmental factor in which plants grow, whether or not plants can survive in a given area depends on temperature; in particular, the minimum temperature can be an important factor in the survival of plants. Each plant has its own survival strategy for yearly getting through the winter and passing on to the next generation (Galan de Mera et al., 1999). In addition, plants have cold tolerance through various physiological mechanisms to survive below a certain temperature (Guy, 1990; Hunter and Lechowicz, 1992). The degree of cold tolerance for each plant is an important measure for determining whether the plant can be cultivated in the area, as well as whether a plant can grow wild in an area (Daly et al., 2012). In this regard, the US Department of Agriculture developed a plant hardiness zone map (PHZM)

This study was conducted with the support of the basic research project by the National Institute of Horticultural Herbal Science under the Rural Development Administration (Project No. PJ01602401).

Received: August 31, 2021, Revised: September 22, 2021, Accepted: October 14, 2021

First author: Jung Nam Suh, suhjn@korea.kr, (1) https://orcid.org/0000-0002-6191-8400

*Corresponding author: Yong Hyun Kim, yonghyunkim@korea.kr, (1) https://orcid.org/0000-0003-1913-3041 
for the United States by classifying plant hardiness zones based on the minimum temperature throughout the year using meteorological data collected from all over the United States (USDA, 1965). The PHZM is broadly divided into 13 zones, and further sub-divided into 26 half zones (Daly et al., 2012). Since the USDA published the PHZM, many countries such as Europe, Canada, Japan, China, Australia, Turkey, and Albania have made and used similar maps using their own meteorological data (Mckenney et al., 2014; Teqja et al., 2017). Plant hardiness zones are widely used throughout the agricultural industry since they serve as an important criterion for determining which plants can be grown in a given area (Widrlechner et al., 2012). In United States and Europe, where gardening culture is widely accepted, the plant hardiness zone is used to select appropriate plants in private garden (Daly et al., 2012; Widrlechner et al., 2012).

Recently, the research on global warming has been conducted in various fields. Chung and Yun (2008) reported the effect of increase in winter temperatures in East Asia on dormancy depth of fruit trees, and decreased the area where fruit trees can overwinter accordingly, they suggested measures for adaptation to climate change, such as relocating fruit trees to a suitable cultivation region or introducing exotic fruit trees that can winter. In the field of landscaping, research is also being conducted on the planting of various ornamental or landscaping broad leaf evergreens in the central region due to climate change (Kim et al., 2010; Kim et al., 2016).

Krakauer (2018) reported that from 1970 to 2016, the annual minimum temperature had increased by 1.5 to $2.5^{\circ} \mathrm{C}$ in the cold regions where the annual minimum temperature was $-10^{\circ} \mathrm{C}$ or lower, and the annual minimum temperature had also increased by less than $1{ }^{\circ} \mathrm{C}$ in the tropical regions where the annual minimum temperature was $0^{\circ} \mathrm{C}$ or higher. However, the results of the study only covered North America, Europe, and North Asia between latitudes $30^{\circ}$ and $60^{\circ} \mathrm{N}$. Teqja et al. (2017) studied the impacts of climate change scenarios on the plant hardiness zones of Albania. They expected that the coldest zone in Albania, Zone 6a, would gradually disappear over time due to global warming, while that the size of the warm Zone 10a would increase, and proposed the introduction of new crops.

Suh and Huh (2011) reported that plant hardiness zones of Korea ranged from Zone 6a to Zone 9b, based on the results of an analysis using data from 76 meteorological stations in Korea for 20 years from 1990 to 2009. These results were also confirmed to be consistent with the findings of Cho et al. (2013), which classified plant hardiness zones using data over a 30-year period from 1981 to 2010 . Our study collected the extended scope of data for 40 years from 1981 to 2020 as a follow-up to the previous study of Suh and Huh (2011); based on the collected data, plant hardiness zones (PHZs) were classified, and the effect of global warming on PHZs was examined, as well as the chronological changes in the annual extreme minimum temperature. We also investigated to determine factors affecting the distribution of evergreen trees in Seoul, Suwon, Jinju, and Suncheon, which are classified within the same plant hardiness zone, $7 \mathrm{~b}$.

\section{Research Methods}

\section{Data collection}

To determine the mean annual extreme minimum temperature based on the USDA plant hardiness zone criteria, temperature analysis data from January 1, 1981 to December 31, 2020, obtained from a total of 103 meteorological observation points nationwide, were extracted from the KMA Open MET Data Portal (data.kma.go.kr). For chronological comparison on the data for 40 years, meteorological observation points that did not have all meteorological data from January 1, 1981 to December 31, 2020 were excluded from the total of 103 points. Therefore, as shown in Table 1 , this study was conducted using data from a total of 60 meteorological observation points(Table 1).

\section{Data collection and analysis method}

\section{Data rearrangement for analysis}

The average temperature, minimum temperature, and maximum temperature data, which were raw temperature data extracted from the KMA Open MET Data Portal, were collected and arranged using Microsoft EXCEL. After annual extreme minimum temperature was calculated, and $60 \mathrm{PHZs}$ were classified based on USDA plant hardiness zone criteria (Widrlechner et al., 2012). In addition, for a comparative 
Table 1. Region with meteorological measurement for 40-years

\begin{tabular}{|c|c|c|}
\hline Province & Region & No. \\
\hline Gyeonggi & Ganghwa, Icheon, Incheon, Seoul, Suwon, Yangpyeong & 6 \\
\hline Gangwon & Chuncheon, Daegwannyeong, Gangneung, Hongcheon, Inje, Sokcho, Wonju & 7 \\
\hline Jeolla & Buan, Gwangju, Gunsan, Namwon, Imsil, Jeonju, Jeongeup, Goheung, Mokpo, Yeosu, Wando, Jangheung, Haenam & 13 \\
\hline Chungcheong & Daejeon, Boeun, Jecheon, Cheongju, Chupungnyeong, Chungju, Geumsan, Boryeong, Buyeo, Seosan, Cheonan & 11 \\
\hline Gyeongsang & $\begin{array}{l}\text { Busan, Daegu, Geochang, Geoje, Gumi, Hapcheon, Jinju, Miryang, Mungyeong, Namhae, Pohang, Sancheong, } \\
\text { Tongyeong, Uiseong, Uljin, Ulleung, Ulsan, Yeongcheon, Yeongdeok, Yeongju }\end{array}$ & 20 \\
\hline Jeju & Seogwipo, Seongsan, Jeju & 3 \\
\hline
\end{tabular}

Note. $\mathrm{N}=60$.

analysis of the regions belonging to Zone $7 \mathrm{~b}$, the following data were extracted for Seoul, Suwon, Suncheon, and Jinju: mean of daily minimum temperature (MMT) for DecemberJanuary; 40-year mean of yearly lowest value on daily maximum temperature for December-February; the number of days on the year when the maximum temperature is below $-1{ }^{\circ} \mathrm{C}$, $-2^{\circ} \mathrm{C}$, and $-3^{\circ} \mathrm{C}$; daily maximum temperature(DMT) before day of yearly extreme minimum temperature for DecemberFebruary; DMT a day of yearly extreme minimum temperature for December-February; DMT after day of yearly extreme minimum temperature for December-February; and the duration of DMT below zero after the annual EMT.

\section{Analysis method}

Statistical analysis and graphing were performed using the IBM SPSS 22 Statistics software package. Descriptive statistical analysis and one-way ANOVA were conducted on the values derived through data rearrangement at a significance level of $95 \%$.

\section{Results and Discussion}

\section{Classification of plant hardiness zones in Korea}

\section{Plant hardiness zones based on data from 1980 to 2020}

Table 2 and Fig. 1 shows the results of classifying 60 meteorological observation points by applying the PHZ criteria to the mean annual EMT for 40 years from 1981 to 2020. In Korea, PHZs were determined to range from 6 a to $9 \mathrm{~b}$, which is consistent with the findings reported in previous studies (Suh and Huh, 2011; Cho et al., 2013). However, the distribution status by PHZ was found to be slightly different from that reported by Cho et al. (2013). Our study revealed that Zone $7 \mathrm{~b}$ is the most broadly distributed, with 15 regions (25.0\%), followed by Zone 8a with 14 (23.3\%), Zones 7a and 8b with 10 (16.7\%) each, Zone 6b with $6(10.0 \%)$, 9b with 3 (5.0\%), and Zones 6a and 9a with 1 (1.7\%), respectively. Cho et al. (2013) reported that Zone 7a had the highest distribution, covering $29.5 \%$ of Korea, followed by Zone $7 \mathrm{~b}$ with $19.3 \%$

Table 2. Classification of plant hardiness zone in Korea

\begin{tabular}{|c|c|c|c|c|c|}
\hline \multirow{2}{*}{ Zone } & & \multirow{2}{*}{$\begin{array}{l}\text { Temperature range } \\
\qquad\left({ }^{\circ} \mathrm{C}\right)\end{array}$} & \multicolumn{2}{|c|}{ No. } & \multirow{2}{*}{ Region } \\
\hline & & & Fre. & $\%$ & \\
\hline \multirow{2}{*}{ Zone 6} & a & $-23.3 \sim-20.6$ & 1 & 1.7 & Daegwannyeong \\
\hline & $\mathrm{b}$ & $-20.6 \sim-17.8$ & 6 & 10.0 & Chuncheon, Hongcheon, Inje, Jecheon, Uiseong, Yangpyeong \\
\hline \multirow[b]{2}{*}{ Zone 7} & a & $-17.8 \sim-15.0$ & 10 & 16.7 & Boeun, Buyeo, Cheonan, Chungju, Ganghwa, Geumsan, Icheon, Imsil, Yeongju, Wonju \\
\hline & $\mathrm{b}$ & $-15.0 \sim-12.2$ & 15 & 25.0 & $\begin{array}{l}\text { Buan, Cheongju, Chupungnyeong, Daejeon, Geochang, Gumi, Hapcheon, Incheon, Jinju, } \\
\text { Mungyeong, Namwon, Seosan, Seoul, Suwon, Yeongcheon }\end{array}$ \\
\hline \multirow[t]{2}{*}{ Zone 8} & $\mathrm{a}$ & $-12.2 \sim-9.4$ & 14 & 23.3 & $\begin{array}{l}\text { Boryeong, Daegu, Haenam, Gangneung, Goheung, Gunsan, Jangheung, Jeongeup, Jeonju, } \\
\text { Miryang, Sancheong, Sokcho, Uljin, Yeongdeok }\end{array}$ \\
\hline & b & $-9.4 \sim-6.7$ & 10 & 16.7 & Busan, Geoje, Gwangju, Mokpo, Namhae, Pohang, Tongyeong, Ulleung, Ulsan, Yeosu \\
\hline \multirow{2}{*}{ Zone 9} & a & $-6.7 \sim-3.9$ & 1 & 1.7 & Wando \\
\hline & $\mathrm{b}$ & $-3.9 \sim-1.1$ & 3 & 5.0 & Jeju, Seogwipo, Seongsan \\
\hline
\end{tabular}

Note. $\mathrm{N}=60$. 
coverage, Zone $6 \mathrm{~b}$ with $18.4 \%$, and Zone $8 \mathrm{a}$ with $17.7 \%$. The reason for this difference may be resulted from the difference in the period and/or area investigated.

\section{Mean annual extreme minimum temperature (EMT) and chronological changes by $\mathrm{PHZ}$}

(1) Zone 6

Zone 6, which is classified as the coldest zone in Korea, was found to be distributed through 7 regions (Table 3). Specifically, Daegwannyeong was the only region belonging to Zone $6 \mathrm{a}$ with an EMT in the range of $-23.3{ }^{\circ} \mathrm{C}$ to $-20.6{ }^{\circ} \mathrm{C}$; for the chronological changes, MEMT rose to Zone $6 \mathrm{~b}$ level in the 1990s, but has been maintained at a Zone 6a level

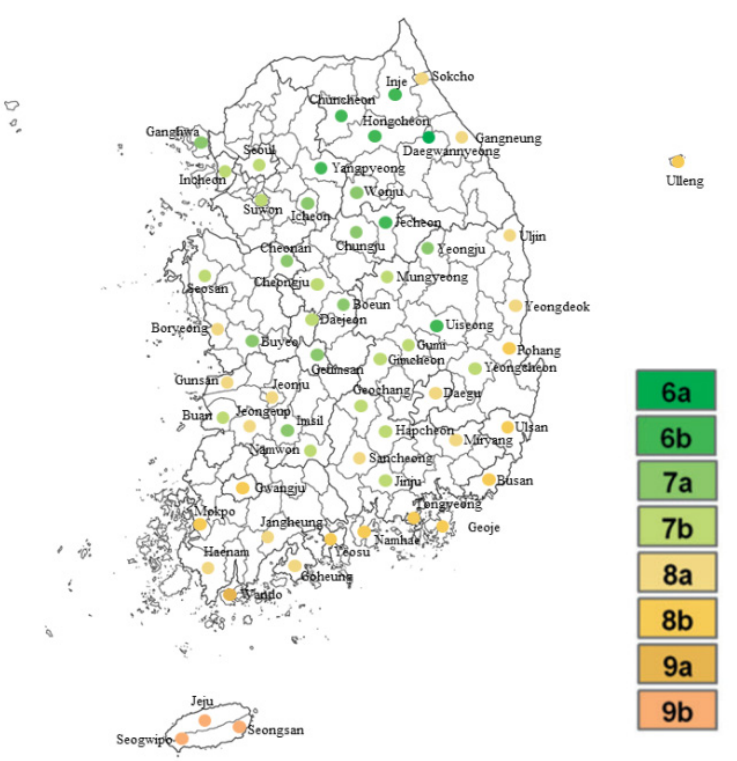

Fig. 1. Plant hardiness map in Korea. after returning to that level in the 2000s, and this change was not significantly different.

Zone $6 \mathrm{~b}$, where the EMT ranges from $-20.6{ }^{\circ} \mathrm{C}$ to $-17.8^{\circ} \mathrm{C}$, was found to be distributed in 6 regions including Inje, Chuncheon, Hongcheon, Yangpyeong, Uiseong, and Jecheon. Chronological change of PHZ was found in Hongcheon and Yangpyeong. In case of Hongcheon, PHZ changed from Zone 6a in the 1980 s to Zone $6 \mathrm{~b}$ in the $1990 \mathrm{~s}$, and remained at the Zone $6 \mathrm{~b}$ thereafter. Yangpyeong belonged to Zone 6a in the 1980s, but it underwent severe changes in MEMT to reach Zone $7 \mathrm{a}$ in the 1990s; and then, the temperature saw repeated fluctuations, decreasing to the Zone $6 \mathrm{~b}$ level in the 2000s and rising again to the Zone 7a level in the 2010s. Based on MEMT for 40 years, Yangpyeong was classified as Zone $6 \mathrm{~b}$.

These results are also supported by the findings of several studies, which report that due to the effects of global warming, the colder the region, the greater the change in the annual EMT, which is the criterion for the classification of PHZs. Parker and Abazoglou (2016) found that in the United States, the annual EMT increased by $1.7{ }^{\circ} \mathrm{C}$ in the southeastern region during the observation period from 1979 to 2012, while it increased by more than $5{ }^{\circ} \mathrm{C}$ in the more northern midwestern and northern regions. In addition, Krakauer (2018) reported that annual EMT has increased by $1.5-2.5{ }^{\circ} \mathrm{C}$ in cold regions where annual EMT was below $-10{ }^{\circ} \mathrm{C}$, but has risen by less than $1{ }^{\circ} \mathrm{C}$ in tropical regions where annual EMT was above $0{ }^{\circ} \mathrm{C}$. In the results of this study, changes in MEMT with a similar tendency to those of the above studies were also found, but it is considered that these temperature changes did not accompany a significant change in zone category for all regions classified as Zone $6 \mathrm{~b}$.

Table 3. Changes in mean extreme minimum temperature for each decade in Zone 6

\begin{tabular}{|c|c|c|c|c|c|c|c|c|c|c|c|c|c|c|c|c|c|}
\hline \multirow{2}{*}{ Region } & \multicolumn{3}{|c|}{$1980 \mathrm{~s}$} & \multicolumn{3}{|c|}{$1990 \mathrm{~s}$} & \multicolumn{3}{|c|}{$2000 \mathrm{~s}$} & \multicolumn{3}{|c|}{$2010 \mathrm{~s}$} & \multicolumn{3}{|c|}{ Total } & \multirow{2}{*}{$\mathrm{F}$} & \multirow{2}{*}{$p$} \\
\hline & Mean & $\mathrm{SD}$ & Zone & Mean & SD & Zone & Mean & $\mathrm{SD}$ & Zone & Mean & $\mathrm{SD}$ & Zone & Mean & $\mathrm{SD}$ & Zone & & \\
\hline Daegwannyeong & -23.02 & 2.38 & $6 a$ & -20.05 & 1.52 & $6 b$ & -21.85 & 3.41 & $6 a$ & -22.23 & 2.39 & $6 a$ & -21.79 & 2.66 & $6 a$ & 2.497 & .075 \\
\hline Chuncheon & -20.07 & 3.50 & $6 b$ & -16.70 & 0.91 & $7 \mathrm{a}$ & -18.46 & 3.08 & $6 \mathrm{~b}$ & -18.96 & 3.09 & $6 b$ & -18.55 & 2.99 & $6 b$ & 2.456 & .079 \\
\hline Hongcheon & -22.61 & 3.72 & $6 a$ & -18.84 & 1.67 & $6 \mathrm{~b}$ & -20.58 & 3.16 & $6 b$ & -19.28 & 2.94 & $6 \mathrm{~b}$ & -20.33 & 3.22 & $6 b$ & 3.242 & $.033^{*}$ \\
\hline Inje & -20.97 & 3.05 & $6 a$ & -18.65 & 2.39 & $6 b$ & -19.93 & 2.96 & $6 \mathrm{~b}$ & -18.94 & 2.89 & $6 \mathrm{~b}$ & -19.62 & 2.87 & $6 b$ & 1.380 & .264 \\
\hline Uiseong & -18.68 & 2.67 & $6 b$ & -17.21 & 2.01 & $7 \mathrm{a}$ & -17.62 & 1.86 & $7 \mathrm{a}$ & -18.09 & 2.82 & $6 \mathrm{~b}$ & -17.90 & 2.35 & $6 b$ & .708 & .554 \\
\hline Yangpyeong & -22.54 & 5.64 & $6 a$ & -16.72 & 2.05 & $7 a$ & -17.89 & 3.00 & $6 b$ & -16.98 & 2.84 & $7 a$ & -18.53 & 4.23 & $6 b$ & 5.577 & $.003^{* *}$ \\
\hline
\end{tabular}




\section{(2) Zone 7}

Zone 7, which has the largest number of areas in Korea, was examined in detail by dividing it into Zone $7 \mathrm{a}\left(-17.8{ }^{\circ} \mathrm{C}\right.$ to $\left.-15.0{ }^{\circ} \mathrm{C}\right)$ and Zone $7 \mathrm{~b}\left(-15.0{ }^{\circ} \mathrm{C}\right.$ to $\left.-12.2{ }^{\circ} \mathrm{C}\right)$. Significant chronological changes were found in the areas belonging to Zone 7a such as Wonju, Yeongju, Boeun, and Chungju (Table 4). From MEMT data, Wonju belongs to Zone 6a in the 1980s, but changed to the Zone $7 \mathrm{a}$ in the 1990s and maintained until now. Yeongju, Boeun, and Chungju all fell under Zone 6b in the 1980s, but like Wonju, MEMT changed to the Zone 7a level in the 1990s and tended to remain at the same PHZ.

Suwon, Gumi, and Cheongju, belonging to PHZ 7b, showed significant chronological changes in MEMT. Suwon and Cheongju were areas that fell under Zone 7a in the 1980s, but it was revealed that the MEMT rose in the 1990s to the Zone $7 \mathrm{~b}$ level and was maintained until now. On the other hand, for Gumi, the MEMT was at the Zone $7 \mathrm{~b}$ level in the 1980s and 1990s, but increased to the Zone 8a level in the 2000s and 2010s.

\section{(3) Zone 8}

In case of Zone 8, which is distributed in the secondlargest number of areas after Zone 7 in Korea (Table 5), Daegu was only found to show a statistically significant difference in chronological temperature changes in PHZ.

\section{(4) Zone 9}

As for Zone 9 (Table 6), Zone $9 \mathrm{a}\left(-6.7{ }^{\circ} \mathrm{C}\right.$ to $-3.9{ }^{\circ} \mathrm{C}$ ) was found to be distributed only in Wando; its temperature showed a significant change to the Zone $8 \mathrm{~b}$ level for a period of time in the $2000 \mathrm{~s}$, but it was confirmed that the

Table 4. Changes in mean extreme minimum temperature for each decade in Zone 7

\begin{tabular}{|c|c|c|c|c|c|c|c|c|c|c|c|c|c|c|c|c|c|}
\hline \multirow{2}{*}{ Region } & \multicolumn{3}{|c|}{$1980 \mathrm{~s}$} & \multicolumn{3}{|c|}{$1990 \mathrm{~s}$} & \multicolumn{3}{|c|}{$2000 \mathrm{~s}$} & \multicolumn{3}{|c|}{$2010 \mathrm{~s}$} & \multicolumn{3}{|c|}{ Total } & \multirow{2}{*}{$\mathrm{F}$} & \multirow{2}{*}{$p$} \\
\hline & Mean & SD & Zone & Mean & SD & Zone & Mean & $\mathrm{SD}$ & Zone & Mean & SD & Zone & Mean & SD & Zone & & \\
\hline Boeun & -20.59 & 3.23 & $6 b$ & -16.26 & 2.25 & $7 a$ & -16.25 & 2.70 & $7 \mathrm{a}$ & -17.47 & 2.88 & $7 \mathrm{a}$ & -17.64 & 3.22 & $7 \mathrm{a}$ & 5.399 & $.004^{* *}$ \\
\hline Buyeo & -16.66 & 3.28 & $7 \mathrm{a}$ & -14.94 & 2.24 & $7 b$ & -14.74 & 2.51 & $7 b$ & -14.66 & 2.75 & $7 \mathrm{~b}$ & -15.25 & 2.74 & $7 a$ & 1.212 & .319 \\
\hline Cheonan & -17.40 & 2.70 & $7 \mathrm{a}$ & -14.72 & 1.75 & $7 b$ & -17.59 & 3.91 & $7 \mathrm{a}$ & -16.34 & 2.90 & $7 \mathrm{a}$ & -16.51 & 3.03 & $7 a$ & 2.036 & .126 \\
\hline Chungju & -20.12 & 5.32 & $6 \mathrm{~b}$ & -15.76 & 1.62 & $7 \mathrm{a}$ & -16.73 & 2.62 & $7 \mathrm{a}$ & -16.90 & 2.71 & $7 \mathrm{a}$ & -17.38 & 3.63 & $7 \mathrm{a}$ & 3.187 & $.035^{*}$ \\
\hline Geumsan & -16.71 & 2.40 & $7 a$ & -16.05 & 1.98 & $7 \mathrm{a}$ & -16.11 & 2.24 & $7 \mathrm{a}$ & -16.37 & 2.91 & $7 \mathrm{a}$ & -16.31 & 2.33 & $7 a$ & .156 & .925 \\
\hline Icheon & -19.32 & 4.12 & $6 \mathrm{~b}$ & -15.59 & 1.40 & $7 \mathrm{a}$ & -17.88 & 3.25 & $6 \mathrm{~b}$ & -17.63 & 2.83 & $7 \mathrm{a}$ & -17.61 & 3.24 & $7 \mathrm{a}$ & 2.511 & .074 \\
\hline Imsil & -19.03 & 3.56 & $6 b$ & -17.33 & 2.56 & $7 \mathrm{a}$ & -16.64 & 3.60 & $7 \mathrm{a}$ & -16.75 & 3.37 & $7 \mathrm{a}$ & -17.44 & 3.32 & $7 \mathrm{a}$ & 1.119 & .354 \\
\hline Yeongju & -18.54 & 2.85 & $6 b$ & -15.06 & 1.67 & $7 \mathrm{a}$ & -15.71 & 2.33 & $7 \mathrm{a}$ & -16.28 & 2.51 & $7 \mathrm{a}$ & -16.40 & 2.64 & $7 \mathrm{a}$ & 4.050 & $.014^{*}$ \\
\hline Wonju & -21.07 & 4.31 & $6 a$ & -16.39 & 1.13 & $7 \mathrm{a}$ & -17.11 & 2.73 & $7 \mathrm{a}$ & -15.69 & 2.66 & $7 \mathrm{a}$ & -17.57 & 3.52 & $7 \mathrm{a}$ & 6.758 & $.001^{* *}$ \\
\hline Cheongju & -17.53 & 2.64 & $7 \mathrm{a}$ & -13.60 & 1.59 & $7 b$ & -14.31 & 2.44 & $7 b$ & -13.06 & 3.19 & $7 b$ & -14.63 & 3.00 & $7 b$ & 6.260 & $.002^{* *}$ \\
\hline Chupungnyeong & -13.80 & 1.76 & $7 b$ & -12.07 & 0.84 & $8 a$ & -13.33 & 2.35 & $7 b$ & -13.93 & 2.23 & $7 b$ & -13.28 & 1.96 & $7 \mathrm{~b}$ & 2.016 & .129 \\
\hline Daejeon & -14.38 & 1.74 & $7 b$ & -12.63 & 1.46 & $7 b$ & -13.45 & 2.32 & $7 b$ & -13.54 & 2.91 & $7 b$ & -13.50 & 2.19 & $7 \mathrm{~b}$ & 1.078 & .371 \\
\hline Geochang & -15.07 & 1.69 & $7 \mathrm{a}$ & -14.09 & 1.98 & $7 b$ & -13.80 & 1.96 & $7 b$ & -14.38 & 2.24 & $7 b$ & -14.34 & 1.96 & $7 b$ & .757 & .526 \\
\hline Gumi & -14.61 & 2.49 & $7 b$ & -12.46 & 2.10 & $7 b$ & -11.46 & 1.74 & $8 a$ & -11.82 & 2.67 & $8 a$ & -12.59 & 2.51 & $7 b$ & 3.835 & $.018^{*}$ \\
\hline Hapcheon & -13.40 & 1.84 & $7 b$ & -11.98 & 1.17 & $8 \mathrm{a}$ & -12.66 & 1.62 & $7 b$ & -13.03 & 1.92 & $7 b$ & -12.77 & 1.68 & $7 b$ & 1.325 & .281 \\
\hline Incheon & -13.74 & 2.55 & $7 b$ & -11.84 & 1.67 & $8 a$ & -12.39 & 3.10 & $7 b$ & -13.09 & 2.84 & $7 b$ & -12.77 & 2.60 & $7 b$ & 1.013 & .398 \\
\hline Jinju & -13.21 & 1.92 & $7 b$ & -11.64 & 1.90 & $8 a$ & -12.60 & 1.69 & $7 b$ & -12.09 & 1.78 & $8 a$ & -12.39 & 1.85 & $7 b$ & 1.375 & .266 \\
\hline Mungyeong & -14.84 & 1.92 & $7 b$ & -12.80 & 0.61 & $7 b$ & -14.15 & 2.57 & $7 b$ & -14.01 & 2.46 & $7 b$ & -13.95 & 2.10 & $7 b$ & 1.721 & .180 \\
\hline Namwon & -14.70 & 2.39 & $7 \mathrm{~b}$ & -15.55 & 3.73 & $7 \mathrm{a}$ & -15.49 & 3.98 & $7 \mathrm{a}$ & -14.22 & 2.93 & $7 \mathrm{~b}$ & -14.99 & 3.24 & $7 \mathrm{~b}$ & .375 & .771 \\
\hline Seosan & -14.17 & 2.77 & $7 \mathrm{~b}$ & -12.87 & 1.92 & $7 b$ & -13.99 & 2.89 & $7 \mathrm{~b}$ & -13.05 & 2.39 & $7 \mathrm{~b}$ & -13.52 & 2.49 & $7 \mathrm{~b}$ & .675 & .573 \\
\hline Yeongcheon & -14.55 & 2.85 & $7 b$ & -13.43 & 1.72 & $7 b$ & -13.10 & 1.47 & $7 b$ & -13.07 & 2.16 & $7 b$ & -13.54 & 2.12 & $7 \mathrm{~b}$ & 1.076 & .372 \\
\hline
\end{tabular}


Table 5. Changes in mean extreme minimum temperature for each decade in Zone 8

\begin{tabular}{|c|c|c|c|c|c|c|c|c|c|c|c|c|c|c|c|c|c|}
\hline \multirow{2}{*}{ Region } & \multicolumn{3}{|c|}{$1980 \mathrm{~s}$} & \multicolumn{3}{|c|}{$1990 \mathrm{~s}$} & \multicolumn{3}{|c|}{$2000 \mathrm{~s}$} & \multicolumn{3}{|c|}{$2010 \mathrm{~s}$} & \multicolumn{3}{|c|}{ Total } & \multirow{2}{*}{$\mathrm{F}$} & \multirow{2}{*}{$p$} \\
\hline & Mean & $\mathrm{SD}$ & Zone & Mean & $\mathrm{SD}$ & Zone & Mean & SD & Zone & Mean & SD & Zone & Mean & SD & Zone & & \\
\hline Boryeong & -13.27 & 2.56 & $7 \mathrm{~b}$ & -12.23 & 2.37 & $7 b$ & -11.30 & 2.55 & $8 \mathrm{a}$ & -11.12 & 2.58 & $8 a$ & -11.98 & 2.57 & $8 a$ & 1.543 & .220 \\
\hline Daegu & -11.38 & 1.26 & $8 a$ & -8.96 & 0.89 & $8 b$ & -9.67 & 2.17 & $8 \mathrm{a}$ & -10.27 & 2.70 & $8 \mathrm{a}$ & -10.07 & 2.03 & $8 a$ & 2.919 & $.047^{\prime}$ \\
\hline Haenam & -9.86 & 2.01 & $8 \mathrm{a}$ & -9.06 & 1.22 & $8 b$ & -11.22 & 2.46 & $8 a$ & -10.83 & 2.08 & $8 a$ & -10.24 & 2.10 & $8 a$ & 2.377 & .086 \\
\hline Gangneung & -11.45 & 1.94 & $8 a$ & -9.86 & 1.37 & $8 a$ & -11.07 & 2.94 & $8 a$ & -10.78 & 2.70 & $8 a$ & -10.79 & 2.31 & $8 a$ & .852 & .475 \\
\hline Gunsan & -10.82 & 2.03 & $8 a$ & -9.07 & 1.25 & $8 b$ & -11.44 & 2.69 & $8 \mathrm{a}$ & -11.40 & 2.44 & $8 a$ & -10.68 & 2.31 & $8 a$ & 2.615 & .066 \\
\hline Jangheung & -10.97 & 2.42 & $8 a$ & -10.07 & 1.51 & $8 a$ & -10.28 & 1.96 & $8 a$ & -10.34 & 2.05 & $8 a$ & -10.42 & 1.96 & $8 a$ & .371 & .775 \\
\hline Jeongeup & -13.38 & 2.12 & $7 b$ & -11.09 & 1.74 & $8 a$ & -12.11 & 2.46 & $8 a$ & -12.19 & 2.46 & $8 a$ & -12.19 & 2.28 & $8 a$ & 1.793 & .166 \\
\hline Jeonju & -12.63 & 1.92 & $7 b$ & -11.16 & 1.71 & $8 a$ & -11.64 & 2.55 & $8 a$ & -11.53 & 2.69 & $8 a$ & -11.74 & 2.23 & $8 a$ & .777 & .514 \\
\hline Miryang & -12.86 & 1.86 & $7 b$ & -11.09 & 1.46 & $8 a$ & -12.19 & 1.46 & $8 a$ & -11.74 & 1.99 & $8 a$ & -11.97 & 1.77 & $8 a$ & 1.898 & .147 \\
\hline Sokcho & -11.41 & 1.94 & $8 a$ & -10.73 & 1.21 & $8 a$ & -12.06 & 2.44 & $8 a$ & -11.93 & 2.73 & $8 a$ & -11.53 & 2.14 & $8 a$ & .784 & .511 \\
\hline Uljin & -11.09 & 1.60 & $8 a$ & -9.45 & 1.03 & $8 a$ & -10.11 & 2.38 & $8 a$ & -10.33 & 2.83 & $8 a$ & -10.25 & 2.09 & $8 a$ & 1.056 & .380 \\
\hline Yeongdeok & -11.44 & 1.77 & $8 a$ & -9.79 & 1.00 & $8 a$ & -10.88 & 2.49 & $8 \mathrm{a}$ & -11.17 & 3.00 & $8 a$ & -10.82 & 2.21 & $8 a$ & 1.084 & .368 \\
\hline Busan & -9.07 & 1.49 & $8 b$ & -6.73 & 1.25 & $8 b$ & -7.81 & 2.47 & $8 b$ & -7.97 & 2.54 & $8 b$ & -7.90 & 2.12 & $8 b$ & 2.241 & .100 \\
\hline Geoje & -8.42 & 1.45 & $8 b$ & -7.29 & 1.16 & $8 b$ & -7.61 & 2.13 & $8 \mathrm{~b}$ & -6.83 & 2.14 & $8 b$ & -7.54 & 1.80 & $8 b$ & 1.426 & .251 \\
\hline Gwangju & -9.90 & 1.61 & $8 a$ & -8.60 & 1.62 & $8 b$ & -9.43 & 2.24 & $8 \mathrm{a}$ & -9.37 & 2.02 & $8 b$ & -9.33 & 1.88 & $8 b$ & .809 & .497 \\
\hline Mokpo & -7.51 & 1.71 & $8 b$ & -6.47 & 1.84 & $9 \mathrm{a}$ & -7.66 & 2.16 & $8 b$ & -7.49 & 2.17 & $8 b$ & -7.28 & 1.96 & $8 b$ & .763 & .522 \\
\hline Namhae & -9.35 & 1.57 & $8 b$ & -7.45 & 1.39 & $8 b$ & -8.49 & 2.08 & $8 b$ & -8.19 & 1.51 & $8 b$ & -8.37 & 1.74 & $8 b$ & 2.246 & .100 \\
\hline Pohang & -10.21 & 1.50 & $8 a$ & -7.85 & 1.37 & $8 b$ & -9.22 & 2.33 & $8 b$ & -9.48 & 2.72 & $8 a$ & -9.19 & 2.16 & $8 b$ & 2.298 & .094 \\
\hline Tongyeong & -8.17 & 1.39 & $8 b$ & -6.47 & 1.70 & $9 a$ & -7.46 & 2.15 & $8 b$ & -7.26 & 1.89 & $8 b$ & -7.34 & 1.84 & $8 b$ & 1.501 & .231 \\
\hline Ulleung & -7.17 & 1.42 & $8 \mathrm{~b}$ & -6.72 & 1.27 & $8 b$ & -7.86 & 2.40 & $8 b$ & -6.75 & 2.40 & $8 b$ & -7.13 & 1.93 & $8 b$ & .746 & .532 \\
\hline
\end{tabular}

Table 6. Changes in mean extreme minimum temperature for each decade in Zone 9

\begin{tabular}{|c|c|c|c|c|c|c|c|c|c|c|c|c|c|c|c|c|c|}
\hline \multirow{2}{*}{ Region } & \multicolumn{3}{|c|}{$1980 \mathrm{~s}$} & \multicolumn{3}{|c|}{$1990 \mathrm{~s}$} & \multicolumn{3}{|c|}{$2000 \mathrm{~s}$} & \multicolumn{3}{|c|}{$2010 \mathrm{~s}$} & \multicolumn{3}{|c|}{ Total } & \multirow{2}{*}{$\mathrm{F}$} & \multirow{2}{*}{$p$} \\
\hline & Mean & SD & Zone & Mean & SD & Zone & Mean & $\mathrm{SD}$ & Zone & Mean & SD & Zone & Mean & SD & Zone & & \\
\hline Wando & -5.56 & 1.38 & $9 \mathrm{a}$ & -4.25 & 2.16 & $9 \mathrm{a}$ & -6.79 & 2.12 & $8 b$ & -6.22 & 1.97 & $9 \mathrm{a}$ & -5.71 & 2.09 & $9 \mathrm{a}$ & 3.185 & $.035^{*}$ \\
\hline Jeju & -2.51 & 1.12 & $9 b$ & -0.62 & 1.08 & $10 \mathrm{a}$ & -1.14 & 1.82 & $9 b$ & -1.06 & 2.28 & $10 \mathrm{a}$ & -1.33 & 1.74 & $9 \mathrm{~b}$ & 2.446 & .080 \\
\hline Seogwipo & -2.87 & 1.17 & $9 b$ & -0.86 & 0.72 & $10 \mathrm{a}$ & -1.71 & 1.80 & $9 b$ & -1.40 & 2.43 & $9 b$ & -1.71 & 1.76 & $9 b$ & 2.619 & .066 \\
\hline Seongsan & -3.65 & 1.54 & $9 b$ & -2.75 & 0.84 & $9 b$ & -2.52 & 1.87 & $9 b$ & -2.62 & 1.85 & $9 b$ & -2.89 & 1.59 & $9 b$ & 1.074 & .372 \\
\hline
\end{tabular}
${ }^{*} p<.05$.

MEMT had increased back to the Zone 9a level in the 2010s. Zone $9 \mathrm{~b}$ was found to be generally distributed in Jeju Island, including Seogwipo, Seongsan, and Jeju. The regions falling under Zone $9 \mathrm{~b}$ showed no significant difference in the change of PHZ resulting from chronological temperature changes.

\section{Temperature affecting the presence of evergreen trees in Zone 7b}

\section{Temperature and daily maximum temperature for the} period January-February

The main variable used to classify plant hardiness zones is the mean annual extreme minimum temperature (Del Tredici, 1990; Magarey et al., 2008). However, this classification does not take into account various variables that distinguish plant hardiness for surviving the winter (Magarey et al., 2008). In 
this regard, even in regions categorized as being in the same PHZ, there may be differences in the distribution of evergreen trees. For example, in Korea, differences in the presence of evergreen trees between the central (Seoul, Suwon) and southern regions (Suncheon, Jinju) belonged to Zone $7 \mathrm{~b}$ is widely acknowledged. While it is difficult to specify a certain area, Bang and Lee (1995), who investigated the distribution of landscaping plants in Korea, reported that the ratio of evergreen to deciduous trees in the Seoul-Gyeonggi region was 28:72, while in Gyeongnam and Jeonnam in the southern region it was 39.2:60.8 and 40.6:59.4, respectively, It suggested that the proportion of evergreen trees was higher in the southern region. Furthermore, Bang and Lee (1995) reported that Camellia japonica L., a representative tree species of evergreen broadleaf forests in the Korean Peninsula, was likely to overwinter in places that could block the north winds in Seoul or Suwon. It seemed to be some factors that hinder the wintering of the species in Seoul and Suwon(PHZ 7b), while Camellia japonica L. belongs to USDA Zones 7-9 (Missouri botanical garden, N.A.). Therefore, we aim to determine temperature factors that distinguish plant hardiness by comparing between the central region (Seoul, Suwon) and the southern region (Jinju, Suncheon), which fall under the same Zone $7 \mathrm{~b}$ but differ in the presence of evergreen trees. In case of Suncheon, the site of observation point changed during our investigated period, it was impossible to collect its annual EMT data for 40 consecutive years. However, based on the data up to 1997 , before the observation point was changed, Suncheon was identified as falling under Zone $7 \mathrm{~b}$ with a MEMT of $12.2{ }^{\circ} \mathrm{C}$.

Plant hardiness zones are classified based on the mean minimum temperature of the coldest month of the year.
Therefore, in this study, Seoul, Suwon, Jinju, and Suncheon were compared using temperature data from December to February, the coldest months in Korea (Table 7). In the analysis of the mean daily minimum temperature (MMT) in December to February, Suwon had the lowest MMT at $-5.9{ }^{\circ} \mathrm{C}$, and Seoul, Jinju, and Suncheon were statistically similar at $-4.8^{\circ} \mathrm{C},-4.9^{\circ} \mathrm{C}$, and $-4.4{ }^{\circ} \mathrm{C}$, respectively. These results indicates that the MMTs of Jinju and Suncheon are similar to that of implying that MMT in cold months does not appear to significantly affect plant hardiness.

Next, through comparing mean yearly lowest value on daily maximum temperature it was confirmed that Seoul had the lowest at $-7.3{ }^{\circ} \mathrm{C}$, followed by Suwon at $-6.3{ }^{\circ} \mathrm{C}$, Suncheon at $-2.3{ }^{\circ} \mathrm{C}$, and Jinju at $-0.5{ }^{\circ} \mathrm{C}$. A statistically significant difference was also found between the central region (Seoul, Suwon) and the southern region (Jinju, Suncheon).

In terms of the number of days in the year when the maximum temperature is below of $-1{ }^{\circ} \mathrm{C},-2{ }^{\circ} \mathrm{C}$, and $-3{ }^{\circ} \mathrm{C}$ from December to February, it was one day or less in the southern regions. On the other hand, in Seoul and Suwon in the central region, the number of days below $-1{ }^{\circ} \mathrm{C}$ was 16.1 days and 13.2 days, the number of days below $-2{ }^{\circ} \mathrm{C}$ was 12.2 days and 9.4 days, and the number of days below $-3{ }^{\circ} \mathrm{C}$ was 8.6 days and 6.3 days, respectively.

\section{Annual daily minimum temperature}

Regarding the annual extreme minimum temperature (EMT), which is the classification standard for plant hardiness maps, we compared the daily maximum temperature (DMT) the day before, the day of, and the day after the annual EMT, and duration of DMT below zero after the annual EMT (Table 8).

Table 7. Mean daily minimum temperature (MMT), mean yearly lowest value on daily maximum temperature (MHLV), the number of days in the year when the maximum temperature is below (MTB) of Seoul, Suwon, Jinju, Suncheon in plant hardiness zone $7 \mathrm{~b}$

\begin{tabular}{|c|c|c|c|c|c|c|}
\hline \multirow{2}{*}{ Item } & Seoul & Suwon & Jinju & Suncheon & \multirow{2}{*}{$\mathrm{F}$} & \multirow{2}{*}{$p$} \\
\hline & \multicolumn{4}{|c|}{$($ Mean \pm SD) } & & \\
\hline $\operatorname{MMT}\left({ }^{\circ} \mathrm{C}\right)$ & $-4.8 \pm 1.6 b^{z}$ & $-5.9 \pm 1.9 \mathrm{a}$ & $-4.9 \pm 1.3 b$ & $-4.4 \pm 1.1 \mathrm{~b}$ & 6.02 & .001 \\
\hline $\operatorname{MHLV}\left({ }^{\circ} \mathrm{C}\right)$ & $-7.3 \pm 2.6 \mathrm{a}$ & $-6.3 \pm 2.4 \mathrm{a}$ & $-0.5 \pm 2.1 \mathrm{c}$ & $-2.3 \pm 2.0 \mathrm{~b}$ & 73.87 & $<.001$ \\
\hline MTB $-1^{\circ} \mathrm{C}$ (days) & $16.1 \pm 9.3 b$ & $13.2 \pm 8.5 b$ & $0.5 \pm 0.8 \mathrm{a}$ & $2.9 \pm 3.2 \mathrm{a}$ & 46.26 & $<.001$ \\
\hline MTB $-2^{\circ} \mathrm{C}$ (days) & $12.2 \pm 7.8 \mathrm{c}$ & $9.4 \pm 7.1 \mathrm{~b}$ & $0.3 \pm 0.5 \mathrm{a}$ & $1.4 \pm 0.8 \mathrm{a}$ & 39.56 & $<.001$ \\
\hline MTB $-3^{\circ} \mathrm{C}$ (days) & $8.6 \pm 6.8 b$ & $6.3 \pm 5.8 b$ & $0.1 \pm 0.3 \mathrm{a}$ & $0.6 \pm 0.8 \mathrm{a}$ & 28.45 & $<.001$ \\
\hline
\end{tabular}

${ }^{\mathrm{z}}$ Different letters in the same column indicate significant difference according to Duncan's multiple range test at $p<.05$. 
Table 8. Difference in daily maximum temperature (DMT) and duration of below zero temperature (DBZ)

\begin{tabular}{|c|c|c|c|c|c|c|}
\hline \multirow{2}{*}{ Item } & Seoul & Suwon & Jinju & Suncheon & \multirow{2}{*}{$\mathrm{F}$} & \multirow{2}{*}{$p$} \\
\hline & \multicolumn{4}{|c|}{$($ Mean \pm SD) } & & \\
\hline DMT $\left(\mathrm{D}-1,{ }^{\circ} \mathrm{C}\right)$ & $-4.7 \pm 3.7 \mathrm{a}^{\mathrm{z}}$ & $-5.1 \pm 2.7 \mathrm{a}$ & $1.8 \pm 3.2 \mathrm{c}$ & $0.0 \pm 2.5 \mathrm{~b}$ & 57.45 & $<.001$ \\
\hline DMT (D-day, $\left.{ }^{\circ} \mathrm{C}\right)$ & $-6.2 \pm 3.3 \mathrm{a}$ & $-3.4 \pm 3.2 b$ & $4.8 \pm 2.6 \mathrm{c}$ & $3.5 \pm 3.4 \mathrm{c}$ & 90.87 & $<.001$ \\
\hline $\operatorname{DMT}\left(\mathrm{D}+1,{ }^{\circ} \mathrm{C}\right)$ & $-2.0 \pm 3.4 \mathrm{a}$ & $0.9 \pm 3.5 \mathrm{~b}$ & $7.5 \pm 3.4 \mathrm{~d}$ & $5.2 \pm 4.4 \mathrm{c}$ & 59.45 & $<.001$ \\
\hline DBZ (day) & $2.1 \pm 2.7 \mathrm{~b}$ & $0.7 \pm 1.2 \mathrm{a}$ & $0.0 \pm 0.0 \mathrm{a}$ & $0.0 \pm 0.2 \mathrm{a}$ & 14.70 & $<.001$ \\
\hline
\end{tabular}

Note, D-1 = before day of yearly extreme minimum temperature; D-day = a day of yearly extreme minimum temperature; D $+1=$ after day of yearly extreme minimum temperature.

${ }^{\mathrm{z} D i f f e r e n t ~ l e t t e r s ~ i n ~ t h e ~ s a m e ~ c o l u m n ~ i n d i c a t e ~ s i g n i f i c a n t ~ d i f f e r e n c e ~ a c c o r d i n g ~ t o ~ D u n c a n ' s ~ m u l t i p l e ~ r a n g e ~ t e s t ~ a t ~} p<.05$.

In terms of DMT the day before the annual EMT, a significant difference was found between the central region and the southern region; Seoul and Suwon, in the central region, were $-4.7^{\circ} \mathrm{C}$ and $-5.1^{\circ} \mathrm{C}$, respectively, and Jinju and Suncheon, in the southern regions, were $1.8^{\circ} \mathrm{C}$ and $0.0^{\circ} \mathrm{C}$, respectively. Significant differences between the regions also appeared in DMT on the day of the annual EMT, with Seoul having the lowest at $-6.2^{\circ} \mathrm{C}$, followed by Suwon at $-3.4^{\circ} \mathrm{C}$, Suncheon at $0.5^{\circ} \mathrm{C}$, and Jinju at $4.8^{\circ} \mathrm{C}$. DMT the day after the annual EMT was also the lowest in Seoul at -2 . $0^{\circ} \mathrm{C}$, followed by Suwon at $0.9^{\circ} \mathrm{C}$, Suncheon at $4.5^{\circ} \mathrm{C}$, and Jinju at $7.5^{\circ} \mathrm{C}$. In addition, the duration of DMT below zero after the annual EMT was confirmed to be 2.1 days in Seoul, 0.7 days in Suwon and 0 days in Jinju and Suncheon, showing a statistically significant difference between Seoul and the others.

From these results, even if the annual EMT falls below freezing, DMT on the very day or the next day was generally recovered to above zero in Jinju and Suncheon, the southern region. However, in Seoul and Suwon, in the central region, the sub-zero temperatures lasted longer than those in the southern regions.

As such, the continuous sub-zero DMT before and after the annual EMT in the central region made it difficult for plants with cold resistance to survive even in the same Zone $7 \mathrm{~b}$, which it is considered to bring about a difference in the distribution of evergreen plants between the regions, although both regions fall under the same plant hardiness zone.

\section{Conclusion}

Temperature data from the Korea Meteorological Administration from 1981 to 2020 were analyzed to determine plant hardiness zones and their temporal change in Korea. Based on the mean annual EMT in Korea for 40 years, plant hardiness zones were divided according to the temperature criteria of USDA PHZM; as a result, the PHZs were confirmed to be in the range of Zone 6a to Zone 9b. In Korea, Zone $7 \mathrm{~b}$ was found to be the most widely distributed with 15 regions, followed by $8 \mathrm{a}$ (14 regions), $7 \mathrm{a}$ and $8 \mathrm{~b}$ (10 regions each), $6 \mathrm{~b}$ (6 regions), $9 \mathrm{~b}$ ( 3 regions), and $6 \mathrm{a}$ and $9 \mathrm{a}$ (1 region each). When investigating the effect of global warming on the changes in the annual EMT, it was confirmed that in some areas such as Yangpyeong and Wonju, the annual EMT increased due to urbanization, so their zone category were changed.

Differences in the fluctuation pattern of DMT in winter between central region(Seoul and Suwon) and southern region(Jinju and Suncheon) in Korea, which are all classified as Zone $7 \mathrm{~b}$ but different distribution of evergreen broadleaf trees, were elucidated. In the central region, the DMT the day before or the day of the annual EMT continued to be below zero, but in the southern region, the DMT the day before or the day of the annual EMT was maintained above zero. These findings suggest that the duration of sub-zero temperatures above a certain level is a crucial factor affecting the cold tolerance of evergreen trees in PHZ 7b. A limitation of this study is that in the process of selecting regions where all temperature data for 40 years were confirmed, many regions in Korea were excluded, so only 60 regions were classified as plant hardiness zones. Despite this limitation, this study shows that sub-zero temperature duration can contribute to the differences in the distribution of evergreen broadleaf trees in 
regions falling under the same plant hardiness zone.

\section{References}

Bang, K.J. and J.S. Lee. 1995. Studies on planting distribution status of landscaping plants in Korea. J. Korean Inst. Landsc. Archit. 23(1):67-94.

Cho, J.G., S.H. Kim, J.H. Han, J.G. Park, and J.G. Kim. 2013. Development of plant hardiness zone map of Korea on the Basis of USDA. Korean J. Hortic. Sci. Technol. 31(Suppl. I ):113.

Chung, U.R., S.O. Kim, and J.I. Yun, 2008. Plant hardiness zone mapping based on a combined risk analysis using dormancy depth index and low temperature extremes-a case study with. Korean J. Agric. For. Meteorol. 10(4):121-131. https://doi.org/10.5532/KJAFM.2008.10.4.121

Chung, U.R. and J.I. Yun. A prospect on the changes in short-term cold hardiness in "Campbell Early" grapevine under the future warmer winter in South Korea. Korean J. Agric. For. Meteorol. 10(3):94-101. https://doi.org/10. 5532/KJAFM.2008.10.3.94

Daly, C., M.P. Widrlechner, M.D. Halbleib, J.I. Smith, and W.P. Gibson. 2012. Development of a new USDA plant hardiness zone map for the United States. J. Appl. Meteorol. Climatol. 51(2):242-264. https://doi.org/10.1175/2010JAMC2536.1

Del Tredici, P. 1990. The new USDA plant hardiness zone map. Arnoldia 50(3):16-20.

Galán de Mera, A., M.A. Hagen, and J.A. Vicente Orellana. 1999. Aerophyte, a new life form in Raunkiaer's classification? J. Veg. Sci. 10(1):65-68. https://doi.org/10.2307/3237161

Guy, C.L. 1990. Cold acclimation and freezing stress tolerance: role of protein metabolism. Annu. Rev. Plant Biol. 41(1): 187-223. https://doi.org/10.1146/annurev.pp.41.060190. 001155

Hunter, A.F. and M.J. Lechowicz. 1992. Predicting the timing of budburst in temperate trees. J. Appl. Ecol. 29(3):597-604. https://doi.org/10.2307/2404467

Kim I.H., K.Y. Huh, and M.R. Huh. 2010. Cold tolerance assessment of Sedum species for shallow-extensive green roof system. Korean J. Hortic. Sci. Technol. 28(1):22-30

Kim J.M., S.M. Choi, and K.Y. Huh. 2016. Comparative assessment on cold tolerance of broad-leaved evergreen trees grown in southern region for urban greening. J. People Plants Environ. 19(2):71-78. https://doi.org/10.1 1628/ksppe.2016.19.2.71

Krakauer, N.Y. 2018. Shifting hardiness zones: Trends in annual minimum temperature. Climate 6(1):15. https://d oi.org/10.3390/cli6010015

Magarey, R.D., D.M. Borchert, and J.W. Schlegel. 2008. Global plant hardiness zones for phytosanitary risk analysis. Sci. Agric. 65:54-59. https://doi.org/10.1590/S0103-901 62008000700009

Mckenney, D.W., J.H. Pedlar, K. Lawrence, P. Papadopol, K. Campbell, and M.F. Hutchinson. 2014. Change and evolution in the plant hardiness zones of Canada. BioScience 64(4):341-350. https://doi.org/10.1093/biosci/biu016

Missouri Botanical Garden. N.A. Camellia japonica. Retrieved from https://www.missouribotanicalgarden.org

Parker, L.E. and J.T. Abatzoglou. 2016. Projected changes in cold hardiness zones and suitable overwinter ranges of perennial crops over the United States. Environ. Res. Lett. 11(3):034001. https://doi.org/10.1088/1748-9326/1 $1 / 3 / 034001$

Suh J.N. and M.R. Huh. 2011. Plant hardiness zone map of Korea by average minimum temperature. Korean J. Hortic. Sci. Technol. 29(Suppl. II):52.

Teqja, Z., A. Kopali, Z. Libohova, and P.R. Owens. 2017. A study of the impacts of climate change scenarios on the plant hardiness zones of Albania. J. Appl. Meteorol. Climatol. 56(3):615-631. https://doi.org/10.1175/JAMCD-16-0108.1

U.S. Department of Agriculture (USDA). 1965. Plant hardiness zone map for the United States (revised). USDA Misc. Publ. 814 (revised).

Widrlechner, M.P., C. Daly, M. Keller, and K. Kaplan. 2012. Horticultural applications of a newly revised USDA Plant Hardiness Zone Map. HortTechnology 22(1):6-19. https://doi.org/10.21273/HORTTECH.22.1.6 